\title{
CHEMICAL AND ENERGETIC CHARACTERIZATION OF Eucalyptus grandis $\times$ Eucalyptus urophylla CLONES SUBJECT TO WIND DAMAGE
}

Antonio José Vinha Zanuncio ${ }^{2 *}$, Amélia Guimarães Carvalho² ${ }^{\odot}$, Angelica de Cassia Oliveira Carneiro ${ }^{3} \odot$, Jorge Luiz Colodette ${ }^{3}\left[\right.$ and Maria Fernanda Vieira Rocha ${ }^{4}[$

\footnotetext{
${ }^{1}$ Received on 19.11.2015 accepted for publication on 04.10.2017.

${ }^{2}$ Universidade Federal de Uberlândia, Instituto de Ciências Agrarias, Monte Carmelo, MG - Brasil. E-mail:<ajvzanuncio@yahoo.com.br> and <ameliagcarvalho@gmail.com>.

${ }^{3}$ Universidade Federal de Viçosa, Departamento de Engenharia Florestal, Viçosa, MG - Brasil. E-mail: <cassiacarneiro1@gmail.com> and <colodett@ufv.br>.

${ }^{4}$ Universidade Federal de Lavras, Departamento de Ciências Florestais, Lavras, MG - Brasil. E-mail: <mfvrocha@yahoo.com.br>.

*Corresponding author.
}

\begin{abstract}
Wind damages are common in forest plantations and the use of this wood can minimize losses. The objective was to evaluate the chemical composition and the energetic potential of wood and charcoal from trees subject to wind damage. Eight (A to H) two-years-old Eucalyptus grandis $\times$ Eucalyptus urophylla clones were selected in a region where wind damage is frequent. The basic density, calorific value, chemical composition of wood and calorific value, immediate chemistry and gravimetric yield of charcoal were determined for all clones. Materials with high lignin content and low S/G ratio had higher gravimetric yield. The energy density of wood and charcoal showed high relationship with the basic and apparent relative density, respectively. All materials showed potential for bioenergy, but the clone E stood out with higher gravimetric yield and energy density.
\end{abstract}

Keywords: Calorific value; Charcoal; Lignin.

\section{CARACTERIZAÇÃO QUÍMICAE ENERGÉTICA DE CLONES DE Eucalyptus grandis $\times$ Eucalyptus urophylla SUJEITOS A DANOS PELOS VENTOS}

RESUMO - Danos por ventos são frequentes em plantações florestais, e a utilização desta madeira pode minimizar os prejuizos causados. O objetivo foi avaliar a composição química e o potencial energético da madeira e carvão de árvores sujeitas a danos pelos ventos. Oito clones de Eucalyptus grandis $\times$ Eucalyptus urophylla com idade de dois anos foram selecionados em região onde danos por ventos ocorrem com alta frequência. A densidade básica, poder calorífico, composição química da madeira e poder calorifico, química imediata e rendimento gravimétrico do carvão foram determinados para todos os clones. $O$ rendimento gravimétrico de materiais com alto teor de lignina e baixa relação $S / G$ foi maior. A densidade energética da madeira e carvão apresentou maior relação com a densidade básica e aparente, respectivamente. Todos os materiais apresentaram potencial para bioenergia, mas o clone E se destacou com alto rendimento gravimétrico e densidade energética.

Palavras-Chave: Carvão Vegetal; Lignina; Poder calorífico. 


\section{INTRODUCTION}

The winds are characterized by the air movement from areas with high to low pressures (Moore et al., 2013; Kramer et al., 2014; Hale et al., 2015). Wind damage in forests are reported since 1940 (Mitchell et al., 2012) in many regions of the world (Lagergren et al., 2012; Moore et al., 2013; Kramer et al., 2014).

Wind damages occur mainly from 24 to 36 months old in eucalyptus plants and it can bend or break the trees (CENIBRA, 2014). The first causes loss of apical dominance and reduced the productivity. In the second, it is necessary to harvest broken material and plant a new forest. In both cases, losses are considerable and threaten eucalyptus plantations.

Trees broken by winds are mainly young ones with smaller diameter, low density and poor quality fibers (Veenin et al., 2005; Ramírez et al., 2009), hindering its use in pulp (Severo et al., 2013; Pirralho et al., 2014) and lumber (Luna et al., 2013) production. Therefore, these materials are used mainly for energy purposes (Guerra et al., 2014).

The aim of this study was to characterize the chemical and energetic potential of wood and charcoal from eucalyptus clones subject to wind damage aiming to find a better use for these materials.

\section{MATERIAL AND METHODS}

\subsection{Biological Material}

Three trees per each of eight (A to H) two-yearsold Eucalyptus grandis $\times$ Eucalyptus urophylla different clones were collected in the region of Belo Oriente, Minas Gerais state, Brazil (42²2'30' S and $\left.19^{\circ} 15^{\prime} 00^{\prime} \mathrm{O}\right)$. This age and region were chosen because they have high incidence of wind damage.

Disks were withdrawn at 1.3 meters above ground level, from each felled tree, the basic density, chemical and energetic properties of these materials were analyzed.

\subsection{Wood chemical characterization}

One disk from each tree were milled with a Standard Wiley knife mill with a $2 \mathrm{~mm}$ screen. This material was sieved with a 40-60 mesh sieve and the retained fraction was used to determine the total extractives according to ASTM D-1105-94
(ASTM, 1994); besides the insoluble lignin (Gomide and Demuner, 1986); soluble lignin (Goldschimid, 1971) and Siringil/Guaiacil (S/G) ratio (Lin and Dence, 1992). The total lignin was obtained with the sum of soluble and insoluble lignin. Finally, the holocellulose content was determined by subtracting these components from 100.

The same sample was used for elemental analysis. The carbon, hydrogen and nitrogen content, based in wood dry mass, were quantified with a universal analyzer Vario Microcube model. The oxygen content was obtained by subtracting the carbon, hydrogen and nitrogen from 100.

\subsection{Physical and energetic characterization of wood and charcoal}

The wood basic density was determined according to NBR 11941 (ABNT, 2003), the gross calorific value according to NBR 8633 (ABNT, 1984) and the wood energy density by the product of these two parameters.

The wood was carbonized at $1.67^{\circ} \mathrm{C} / \mathrm{min}$ heating rate, until $450^{\circ} \mathrm{C}$ and $30 \mathrm{~min}$ residence time in electric furnace at atmospheric pressure and controlled presence of oxygen. The ash, volatile matter and fixed carbon were evaluated according to ABNT NBR 8112 (ABNT, 1983): the gross calorific value according to ABNT NBR 8633 (ABNT, 1983) and apparent relative density according to ABNT NBR 9165 (ABNT, 1985). The charcoal energy density was determined by the product of the apparent relative density and gross calorific value. The elemental analysis of charcoal was performed similarly to that of the timber.

\subsection{Statistical analysis}

The variance homogeneity (Bartlett's test at $5 \%$ significance) and normality test were performed (Shapiro-Wilk test at 5\% significance). Means of treatments were compared with the Scott-Knott test at $5 \%$ probability.

\section{RESULTS}

\subsection{Wood chemical characterization}

The extractives, ash, soluble, insoluble and total lignin, holocellulose and the $\mathrm{S} / \mathrm{G}$ ratio of the eight different clones evaluated were determined to characterize the wood (Table 1). 
Chemical and energetic characterization of...

Table 1 - Chemical composition of eight different two-years-old Eucalyptus grandis $\times$ Eucalyptus urophylla clones (Cl.).

Tabela 1 - Composição química de oito diferentes clones de Eucalyptus grandis $\times$ Eucalyptus urophylla (Cl.) com dois anos de idade.

\begin{tabular}{|c|c|c|c|c|c|c|c|}
\hline Cl. & Ext. (\%) & $\operatorname{Ash}(\%)$ & Sol. Lig. (\%) & Ins. Lig (\%) & Tot. Lig. (\%) & $\mathrm{S} / \mathrm{G}$ & Hol. (\%) \\
\hline A & $2.54^{3.7} \mathrm{c}$ & $0.425^{4.7} \mathrm{a}$ & $4.4^{2.1} \mathrm{a}$ & $25.2^{2.3} \mathrm{a}$ & $29.6^{2.7} \mathrm{a}$ & $2.99^{1.8} \mathrm{a}$ & $67.44^{2.5} \mathrm{~b}$ \\
\hline $\mathrm{B}$ & $0.73^{1.6} \mathrm{a}$ & $0.370^{5.3} \mathrm{a}$ & $4.5^{3.4} \mathrm{a}$ & $24.5^{2.4} \mathrm{a}$ & $29.0^{2.6} \mathrm{a}$ & $3.93^{2.2} \mathrm{c}$ & $69.90^{2.7} \mathrm{c}$ \\
\hline $\mathrm{C}$ & $2.25^{3.6} \mathrm{c}$ & $0.450^{5.9} \mathrm{a}$ & $4.1^{3.9} \mathrm{a}$ & $26.4^{2.9} \mathrm{~b}$ & $30.5^{3.2} \mathrm{~b}$ & $3.42^{3.3} \mathrm{~b}$ & $66.8^{3.2} \mathrm{~b}$ \\
\hline $\mathrm{D}$ & $2.95^{3.1} \mathrm{~d}$ & $0.385^{5.7} \mathrm{a}$ & $4.7^{4.1} \mathrm{a}$ & $26.0^{3.7} \mathrm{~b}$ & $30.7^{3.7} \mathrm{~b}$ & $3.11^{2.7} \mathrm{a}$ & $65.97^{3.3} \mathrm{a}$ \\
\hline $\mathrm{E}$ & $1.23^{3.9} \mathrm{~b}$ & $0.405^{6.1} \mathrm{a}$ & $4.3^{4.2} \mathrm{a}$ & $26.8^{4.2} \mathrm{~b}$ & $31.1^{4.1} \mathrm{~b}$ & $3.11^{4.3} \mathrm{a}$ & $67.27^{3.9} \mathrm{~b}$ \\
\hline $\mathrm{F}$ & $2.95^{4.2} \mathrm{~d}$ & $0.420^{5.3} \mathrm{a}$ & $4.7^{2.9} \mathrm{a}$ & $26.3^{3.5} \mathrm{~b}$ & $31.0^{3.3} \mathrm{~b}$ & $2.97^{2.9} \mathrm{a}$ & $65.63^{3.3} \mathrm{a}$ \\
\hline $\mathrm{G}$ & $2.71^{2.8} \mathrm{c}$ & $0.390^{6.3} \mathrm{a}$ & $4.2^{3.2} \mathrm{a}$ & $26.4^{3.8} \mathrm{~b}$ & $30.6^{4.0} \mathrm{~b}$ & $3.31^{2.9} \mathrm{~b}$ & $66.30^{4.0} \mathrm{a}$ \\
\hline $\mathrm{H}$ & $2.17^{3.2} \mathrm{c}$ & $0.405^{5.9} \mathrm{a}$ & $4.1^{3.5} \mathrm{a}$ & $27.8^{4.7} \mathrm{c}$ & $31.9^{4.3} \mathrm{c}$ & $2.98^{3.5} \mathrm{a}$ & $65.53^{4.3} \mathrm{a}$ \\
\hline CI. & \multicolumn{2}{|c|}{ Carbon (\%) } & Oxygen (\%) & \multicolumn{2}{|c|}{ Hydrogen (\%) } & \multicolumn{2}{|c|}{ Nitrogen (\%) } \\
\hline$\overline{\mathrm{A}}$ & \multicolumn{2}{|c|}{$50.78^{4.8} \mathrm{a}$} & $42.58^{4.6} \mathrm{a}$ & \multicolumn{2}{|c|}{$5.88^{5.2} \mathrm{a}$} & \multicolumn{2}{|c|}{$0.02^{5.2} \mathrm{a}$} \\
\hline $\mathrm{B}$ & \multicolumn{2}{|c|}{$50.55^{4.1} \mathrm{a}$} & $42.67^{4.3} \mathrm{a}$ & \multicolumn{2}{|c|}{$5.78^{3.8} \mathrm{a}$} & \multicolumn{2}{|c|}{$0.06^{5.5} \mathrm{a}$} \\
\hline $\mathrm{C}$ & \multicolumn{2}{|c|}{$50.66^{4.0} \mathrm{a}$} & $42.80^{3.4} \mathrm{a}$ & \multicolumn{2}{|c|}{$5.85^{4.2} \mathrm{a}$} & \multicolumn{2}{|c|}{$0.03^{4.1} \mathrm{a}$} \\
\hline $\mathrm{D}$ & \multicolumn{2}{|c|}{$50.49^{3.9} \mathrm{a}$} & $43.02^{4.1} \mathrm{a}$ & \multicolumn{2}{|c|}{$5.76^{4.6} \mathrm{a}$} & \multicolumn{2}{|c|}{$0.03^{4.2} \mathrm{a}$} \\
\hline E & \multicolumn{2}{|c|}{$50.90^{4.5} \mathrm{a}$} & $42.35^{2.8} \mathrm{a}$ & \multicolumn{2}{|c|}{$5.90^{4.2} \mathrm{a}$} & \multicolumn{2}{|c|}{$0.05^{4.4} \mathrm{a}$} \\
\hline $\mathrm{F}$ & \multicolumn{2}{|c|}{$50.77^{4.6} \mathrm{a}$} & $42.63^{3.7} \mathrm{a}$ & \multicolumn{2}{|c|}{$5.89^{4.7} \mathrm{a}$} & \multicolumn{2}{|c|}{$0.08^{4.8} \mathrm{a}$} \\
\hline G & \multicolumn{2}{|c|}{$50.43^{3.7} \mathrm{a}$} & $42.95^{4.1} \mathrm{a}$ & \multicolumn{2}{|c|}{$5.85^{3.6} \mathrm{a}$} & \multicolumn{2}{|c|}{$0.03^{4.7} \mathrm{a}$} \\
\hline $\mathrm{H}$ & \multicolumn{2}{|c|}{$50.30^{4.6} \mathrm{a}$} & $43.28^{3.5} \mathrm{a}$ & \multicolumn{2}{|c|}{$5.82^{4.2} \mathrm{a}$} & \multicolumn{2}{|c|}{$0.07^{4.2} \mathrm{a}$} \\
\hline
\end{tabular}

Ext.= Extractives; Sol. Lig.= soluble lignin; Ins. Lig= Insoluble lignin; Tot. Lig.= Total lignin; $\mathrm{S} / \mathrm{G}=$ syringyl/guaiacyl ratio in the lignin; Hol.= holocellulose. Means followed by the same letter does not differ by the Scott-Knott test at $5 \%$. Values in superscript represent the coefficient of variation.

Ext. = Extrativos; Sol. Lig. = lignina solúvel; Ins. Lig=lignina insolúvel; Tot. Lig. = lignina total; $S / G=$ relação siringil/guaiacil na lignina $;$ Hol.$=$ holocelulose Médias seguidas pela mesma letra não diferem pelo teste de Scott-Knott a 5\%. Valores em sobrescrito representam o coeficiente de variação.

\subsection{Physical and energetic characterization of wood and energy density (Table 2)} and charcoal

The gravimetric yield in charcoal production

The wood of Eucalyptus grandis $\times$ Eucalyptus urophylla clones showed higher basic density, while the charcoal produced presented high calorific value ranged from 30.60 to $33.84 \%$, the fixed carbon from 17.99 to $23.28 \%$, volatile matter from 17.99 to $23.28 \%$ and ash from 0.600 to $0.685 \%$ (Table 3 ).

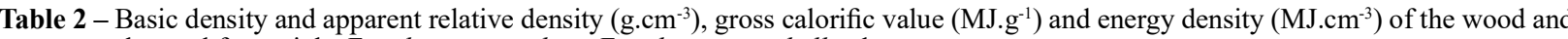
charcoal from eight Eucalyptus grandis $\times$ Eucalyptus urophylla clones.

Tabela 2 - Densidade básica e densidade relativa aparente $\left(\mathrm{g} . \mathrm{cm}^{-3}\right)$, poder calorifico superior $\left(M J \mathrm{~g}^{-1}\right)$ e densidade energética $\left(M J . \mathrm{cm}^{-3}\right)$ da madeira e do carvão vegetal de oito clones de Eucalyptus grandis $\times$ Eucalyptus urophylla

\begin{tabular}{|c|c|c|c|}
\hline \multirow[t]{2}{*}{ Clone } & \multicolumn{3}{|c|}{ Wood } \\
\hline & Basic density & Gross calorific value & $\overline{\text { Energy density }}$ \\
\hline $\mathrm{A}$ & $0.412^{3.1} \mathrm{~b}$ & $19.13^{4.2} \mathrm{a}$ & $7.92^{3.7} \mathrm{c}$ \\
\hline B & $0.331^{4.5} \mathrm{a}$ & $19.95^{4.6} \mathrm{~b}$ & $6.61^{3.8} \mathrm{a}$ \\
\hline $\mathrm{C}$ & $0.372^{4.0} \mathrm{a}$ & $19.80^{4.7} \mathrm{~b}$ & $7.31^{3.4} \mathrm{~b}$ \\
\hline $\mathrm{D}$ & $0.423^{3.6} \mathrm{c}$ & $19.92^{3.5} \mathrm{~b}$ & $8.44^{4.1} \mathrm{~d}$ \\
\hline $\mathrm{E}$ & $0.421^{4.1} \mathrm{c}$ & $19.80^{3.6} \mathrm{~b}$ & $8.31^{3.3} \mathrm{~d}$ \\
\hline $\mathrm{F}$ & $0.370^{3.5} \mathrm{a}$ & $19.79^{4.1} \mathrm{~b}$ & $7.29^{3.7} \mathrm{~b}$ \\
\hline $\mathrm{G}$ & $0.370^{3,9} \mathrm{a}$ & $19.02^{3.8} \mathrm{a}$ & $7.09^{4.2} \mathrm{~b}$ \\
\hline \multirow[t]{3}{*}{$\mathrm{H}$} & $0.383^{3.1} \mathrm{a}$ & $19.96^{4.1} \mathrm{~b}$ & $7.65^{3.9} \mathrm{~b}$ \\
\hline & \multicolumn{3}{|c|}{ Charcoal } \\
\hline & Apparent relative density & Gross calorific value & Energy density \\
\hline $\mathrm{A}$ & $0.305^{2.5} \mathrm{c}$ & $29.68^{4.3} \mathrm{a}$ & $9.01^{3.8} \mathrm{e}$ \\
\hline B & $0.235^{3.1} \mathrm{a}$ & $29.89^{3.7} \mathrm{a}$ & $7.12^{3.2} \mathrm{~b}$ \\
\hline $\mathrm{C}$ & $0.241^{3.4} \mathrm{a}$ & $29.29^{4.8} \mathrm{a}$ & $7.15^{4.2} \mathrm{~b}$ \\
\hline $\mathrm{D}$ & $0.296^{3.6} \mathrm{c}$ & $29.29^{5.1} \mathrm{a}$ & $8.61^{4.2} \mathrm{~d}$ \\
\hline $\mathrm{E}$ & $0.308^{3.4} \mathrm{c}$ & $29.30^{4.5} \mathrm{a}$ & $9.08^{3.7} \mathrm{e}$ \\
\hline $\mathrm{F}$ & $0.227^{3.5} \mathrm{a}$ & $29.30^{3.8} \mathrm{a}$ & $6.68^{3.6} \mathrm{a}$ \\
\hline $\mathrm{G}$ & $0.258^{3.1} \mathrm{a}$ & $29.31^{4.3} \mathrm{a}$ & $7.51^{3.3} \mathrm{~b}$ \\
\hline $\mathrm{H}$ & $0.271^{2.8} \mathrm{~b}$ & $29.31^{4.1} \mathrm{a}$ & $7.94^{3.4} \mathrm{c}$ \\
\hline
\end{tabular}

Means followed by the same letter does not differ by the Scott-Knott test at $5 \%$. Values in superscript represent the coefficient of variation.

Médias seguidas pela mesma letra não diferem pelo teste de Scott-Knott a $5 \%$. Valores em sobrescrito representam o coeficiente de variação 
Table 3 - Gravimetric yield (Grav), fixed carbon (FC), volatile matter (VM), ash (\%) and elemental composition from charcoal of eight Eucalyptus grandis $\times$ Eucalyptus urophylla clones.

Tabela 3 - Rendimento gravimétrico (Grav), carbono fixo (FC), materiais voláteis (VM), cinzas (\%) e composição elementar do carvão de oito clones de Eucalyptus grandis $\times$ Eucalyptus urophylla.

\begin{tabular}{ccccc}
\hline Clone & Grav (\%) & FC (\%) & VM (\%) & Ash (\%) \\
\hline A & $32.29^{4.5} \mathrm{~b}$ & $76.22^{2.5} \mathrm{a}$ & $23.28^{3.5} \mathrm{c}$ & $0.600^{5.5} \mathrm{a}$ \\
$\mathrm{B}$ & $30.96^{4.3} \mathrm{a}$ & $79.86^{3.6} \mathrm{~b}$ & $19.49^{3.7} \mathrm{~b}$ & $0.625^{6.2} \mathrm{a}$ \\
$\mathrm{C}$ & $31.73^{3.2} \mathrm{~b}$ & $81.15^{3.3} \mathrm{c}$ & $18.40^{2.4} \mathrm{a}$ & $0.685^{6.4} \mathrm{a}$ \\
$\mathrm{D}$ & $31.13^{4.1} \mathrm{a}$ & $79.69^{4.1} \mathrm{~b}$ & $19.61^{2.6} \mathrm{~b}$ & $0.660^{5.2} \mathrm{a}$ \\
$\mathrm{E}$ & $33.42^{2.5} \mathrm{c}$ & $23.00^{3.2} \mathrm{c}$ & $0.645^{5.6} \mathrm{a}$ \\
$\mathrm{F}$ & $33.47^{3.3} \mathrm{c}$ & $20.35^{2.7} \mathrm{a}$ & $20.72^{3.6} \mathrm{~b}$ & $0.655^{6.2} \mathrm{a}$ \\
$\mathrm{G}$ & $30.60^{2.7} \mathrm{a}$ & $78.63^{2.8} \mathrm{~b}$ & $17.99^{3.6} \mathrm{a}$ & $0.645^{5.6} \mathrm{a}$ \\
$\mathrm{H}$ & $33.84^{3.6} \mathrm{c}$ & $81.36^{3.4} \mathrm{c}$ & $22.14^{2.9} \mathrm{c}$ & $0.670^{5.2} \mathrm{a}$ \\
\hline Clone & $77.16^{3.2} \mathrm{a}$ & Hydrogen $(\%)$ & Nitrogen $(\%)$ \\
\hline $\mathrm{A}$ & Carbon $(\%)$ & $3.28^{4.3} \mathrm{a}$ & $0.13^{5.6} \mathrm{a}$ \\
$\mathrm{B}$ & $82.38^{4.5} \mathrm{c}$ & $3.20^{4.6} \mathrm{a}$ & $0.12^{6.1} \mathrm{a}$ \\
$\mathrm{C}$ & $80.08^{3.9} \mathrm{~b}$ & $3.20^{4.8} \mathrm{a}$ & $0.09^{5.3} \mathrm{a}$ \\
$\mathrm{D}$ & $81.43^{4.2} \mathrm{c}$ & $3.29^{4.1} \mathrm{a}$ & $0.11^{5.8} \mathrm{a}$ \\
$\mathrm{E}$ & $80.91^{4.1} \mathrm{~b}$ & $\left.11.75^{4.8} \mathrm{~d}\right)$ & $0.16^{6.4} \mathrm{a}$ \\
$\mathrm{F}$ & $78.01^{3.7} \mathrm{a}$ & $14.10^{3.6} \mathrm{c}$ & $3.15^{3.8} \mathrm{a}$ & $0.07^{5.9} \mathrm{a}$ \\
$\mathrm{G}$ & $77.41^{3.8} \mathrm{a}$ & $14.14^{4.2} \mathrm{c}$ & $3.37^{3.4} \mathrm{c}$ & $0.07^{6.0} \mathrm{a}$ \\
$\mathrm{H}$ & $77.68^{4.5} \mathrm{a}$ & $16.08^{3.9} \mathrm{~b}$ & $3.32^{4.0} \mathrm{a}$ & $0.06^{6.4} \mathrm{a}$ \\
\hline
\end{tabular}

Means followed by the same letter does not differ by the Scott-Knott test at $5 \%$. Values in superscript represent the coefficient of variation.

Médias seguidas pela mesma letra não diferem pelo teste de Scott-Knott a 5\%. Valores em sobrescrito representam o coeficiente de variação.

\section{DISCUSSION}

\subsection{Wood chemical characterization}

The clone A showed a lower extractive content, while the clones $\mathrm{D}$ and $\mathrm{F}$ had the highest (Table 1). The extractive content of the eight clones evaluated was lower than those reported for seven-yearsold Eucalyptus grandis $\times$ Eucalyptus urophylla, Eucalyptus urophylla and Eucalyptus paniculata, 3.41 and 9.12\% (Arantes et al., 2011; Zanuncio et al., 2014). The proportion of extractives in the xylem is higher at the heartwood (Adamapoulos et al., 2005), the process that turns sapwood into heartwood is incipient in twoyears-old trees (Sousa et al., 2013; Gominho et al., 2015), resulting in woods with low extractives content. For energy use, some extractive classes, such as those soluble in dichloromethane have high resistance to thermal degradation (Mészáros et al., 2007), which increases charcoal gravimetric yield, gross calorific value and volatile matter (Zanuncio et al., 2014). All materials showed similar ash quantity, which is very resistant, represent impurities and hinder the use of wood for energy (Bustamante-García et al., 2013).

The soluble lignin content of the materials was similar in all the eight clones, therefore, total lignin content followed the trend of insoluble lignin, with higher values for clone $\mathrm{H}$ and lower for $\mathrm{A}$ and $\mathrm{B}$ clones (Table 1). The lignin is important because of its high carbon content (Fengel and Wegener, 1984) and resistance to high temperatures (Varfolomeev et al., 2015), what makes its presence desirable for energy production. The lignin quality also influences the energy use (Pereira et al., 2013), because wood with high $\mathrm{S} / \mathrm{G}$ ratio, as that of clone $\mathrm{C}$, have structure with fewer linkages between carbons, and therefore, lower resistance to thermal degradation (Prasad et al., 2015).

The clones with lower lignin content showed higher holocellulose quantity, as reported for the clone B. Holocellulose has high oxygen content (Sjöströn, 1981) and poor resistance in high temperatures (Moreno and Font, 2015), reducing its calorific value and gravimetric yield (Liu and Han, 2015) and being unwanted in wood for energy production.

All wood materials showed similar elemental composition (Table 1). Materials with high carbon and low oxygen content are most desirable in the wood for energy production, because they increase wood calorific value and the gravimetric yield of carbonization (Soares et al., 2014). High nitrogen content is unwanted due to its pollution potential,

Revista Árvore 2019;43(4):e430401 
generating toxic oxides during charcoal combustion that can induce acid rain and soil acidification (Demirbas, 2004).

\subsection{Physical and energetic characterization of wood and charcoal}

The charcoal from clones with higher wood basic density had higher apparent relative density with Pearson correlation coefficient of 0.891 between these variables (Table 2). This trend was also reported for $E$. grandis $\times$ E. urophylla and E. urophylla with three, four, five and seven years old (Castro et al., 2013). The charcoal with apparent relative density has better mechanical properties and lower fine production and therefore desirable for energy production (Antal and Mok, 1990).

The gross calorific value showed low variation in the wood and charcoal. This parameter is related with wood chemistry, being directly proportional to the lignin (Pereira et al., 2013) and extractives content (Zanuncio et al., 2014), and inversely proportional to that of holocellulose (Liu and Han, 2015). The low variation in wood chemistry resulted in low variation of the calorific value of wood and charcoal.

Carbonization reduced the basic density and increased the gross calorific value of all clones (Table 2), being the second effect with highest proportion, and therefore, the charcoal had higher energy density than the wood in most of the clones selected. This trend was observed for Eucalyptus grandis $\times$ Eucalyptus urophylla with three, five and seven years old (Soares et al., 2014) and for native wood of Luehea divaricata, Casearia sylvestris, Guazuma ulmifolia and Rapanea ferruginea (Costa et al., 2014). The low variation of the gross calorific value of wood and charcoal among clones resulted in high relationship of energy density with wood basic density and charcoal relative apparent density, with Pearson correlation coefficient of 0.973 and 0.998 , respectively.

The gravimetric yield of the clones $\mathrm{E}, \mathrm{F}$ and $\mathrm{H}$ were higher (Table 3), with Pearson's correlation coefficient of 0.6358 and -0.6424 with the total lignin content and $\mathrm{S} / \mathrm{G}$ ratio. The gravimetric yield is the main quantitative parameter for charcoal production (Rousset et al., 2011) showing how the quantity and quality of lignin in the wood are important for carbonization.
Clones $\mathrm{C}$ and $\mathrm{G}$ showed higher fixed carbon and low volatile matter (Table 3 ). High fixed carbon contents result in slow burning of the material and better mechanical properties of charcoal, facilitating its use in steelmaking. On the other hand, a high volatile matter content is important to the calorific value and charcoal reactivity (Antal and Mok, 1990; Demirbas, 2001; Rousset et al., 2011).

The ash content increases after carbonization in all materials (Table 3). This occurred because the minerals in the wood resist to high temperatures and, therefore, do not degrade during carbonization. Thus, the increase in ash percentage was due to the thermal degradation of other constituents (Moreno and Font, 2015). In the furnace for steel production, minerals present in charcoal may adversely affect the mechanical properties of steel, which makes them undesirable in this process (Oliveira et al., 1982).

The charcoal elemental composition varied with the genetic material, unlike the wood elemental composition, showing that the wood behavior at high temperatures can be complex. There was an increase in the carbon content and a decrease in oxygen and hydrogen content in for all materials. Carbon present in greater proportion in wood components with high resistance to thermal degradation, such as lignin, whereas the oxygen and hydrogen are present in in greater proportion in the holocellulose, which has low resistance to high temperatures.

\section{CONCLUSIONS}

The clones $\mathrm{E}, \mathrm{F}$ and $\mathrm{H}$ had higher gravimetric yield, while the A, D and E higher energy density in the wood and charcoal. The gravimetric yield was correlated with the lignin content and $\mathrm{S} / \mathrm{G}$ ratio, while the energy density had a higher relation to density. All clones showed potential for energy generation, especially the clone E, making this an important alternative to use wind broken trees.

\section{ACKNOWLEDGMENT}

To "Coordenação de Aperfeiçoamento de Pessoal de Nível Superior (CAPES), Conselho Nacional de Desenvolvimento Científico e Tecnológico (CNPq)" and "Fundação de Amparo a Pesquisa do Estado de Minas Gerais (FAPEMIG)" for financial support. Celulose Nipo-Brasileira S.A. provided biological material for this study.

\section{Revista Árvore 2019;43(4):e430401}




\section{REFERENCES}

Adamapoulos S, Voulgaridis E, Passialis C. Variation of certain chemical properties within the stem wood of black locust (Robinia pseudoacacia L.). Holzforschung. 2005;63(5):327-33.

American Society for Testing and Materials ASTM. ASTM D -1105: Standard test method for preparation of extractive-free wood. Annual Book of ASTM standards: wood. Philadelphia: 1994.

Antal MJ, Mok WSL. Review of methods for improving the yield of charcoal from biomass. Energy \& Fuels. 1990;4(3):221-5.

Arantes MDC, Trugilho PF, Lima JT, Carneiro ACO, Alves E, Guerreiro MC. Longitudinal and radial variation of extractives and total lignin contents in a clone of Eucalyptus grandis W. Hill ex Maiden x Eucalyptus urophylla ST Blake. Cerne. 2011;17(3):283-91.

Associação Brasileira De Normas Técnicas - ABNT. NBR 8112: análise imediata. Material volátil, cinzas, carbono fixo. Rio de Janeiro: 1983.

Associação Brasileira de Normas Técnicas - ABNT. NBR 8633: carvão vegetal. Determinação do poder calorífico. Rio de Janeiro: 1984.

Associação Brasileira de Normas Técnicas - ABNT. NBR 9165: carvão vegetal. Determinação da densidade relativa aparente, relativa verdadeira e porosidade. Rio de Janeiro: 1985.

Associação Brasileira de Normas Técnicas - ABNT. NBR 11941: madeira. Determinação da densidade básica. Rio de Janeiro: 2003.

Bustamante-García V, Carrillo-Parra A, GonzálezRodríguez H, Ramírez-Lozano RG, Corral-Rivas JJ, Garza-OcañascF. Evaluation of a charcoal production process from forest residues of Quercus sideroxyla Humb. \& Bonpl. in a Brazilian beehive kiln. Industrial Crops and Products. 2013;42(1):169-74.

Castro AFNM, Castro RVO, Carneiro ACO, Lima JE, Santos RC, Pereira BLC, et al. Análise multivariada para seleção de clones de eucalipto destinados à produção de carvão vegetal. Pesquisa Agropecuária Brasileira. 2013;48(6)627-35.
Costa TG, Bianchi ML, Protásio TP, Trugilho PF, Júnior Pereira A. Qualidade da madeira de cinco espécies de ocorrência no cerrado para produção de carvão vegetal. Cerne. 2014;20(1):37-46.

CENIBRA. Avaliação dos danos por vento. Pesquisa e Desenvolvimento Florestal. elatório Técnico: Belo Oriente, 2014.

Demirbas A. Carbonization ranking of selected biomass for charcoal, liquid and gaseous products. Energy Conversion and Management. 2001;42(10):1229-38.

Demirbas A. Combustion characteristics of different biomass fuels. Progress in Energy and Combustion Science. 2004;30(2):219-30.

Fengel D, Wegener G. Wood, chemistry, ultrastructure, reactions. New York: Walter de Gruyter; 1984. 613p.

Gomide JL, Demuner BJ. Determinação do teor de lignina em material lenhoso: método Klason modificado. O Papel. 1986;47(8):36-8.

Gominho J, Lourenço A, Miranda I, Pereira H. Radial and axial variation of heartwood properties and extractives in mature trees of Eucalyptus globulus. Bioresources. 2015;10(1):721-31.

Goldschimid O. Ultravioleta Spectra. In: Sarkanem $\mathrm{KV}$, Ludwing $\mathrm{CH}$. Lignins: ocurrence, formation, structure and reactions. New York: WileyInterscience; 1971. p.241-66.

Guerra SPS, Garcia EA, Lanças KP, Rezende MA, Spinelli R. Heating value of eucalypt wood grown on SRC for energy production. Fuel. 2014;137(1):360-3.

Hale SE, Gardiner B, Peace A, Nicoll B, Taylor P, Pizzirani S. Comparison and validation of three versions of a forest wind risk model. Environmental Modelling \& Software. 2015;68(1):27-41.

Kramer K, Brang P, Bachofen H, Bugmann H, Wohlgemuth T. Site factors are more important than salvage logging for tree regeneration after wind disturbance in Central European forests. Forest Ecology and Management. 2014;331(1):116-28.

Lagergren F, Jönsson AM, Kristina B, Benjamin S. Implementing storm damage in a dynamic vegetation

Revista Árvore 2019;43(4):e430401 
model for regional applications in Sweden. Ecological Modelling. 2012:247(1):71-82.

Lin SY, Dence CW. Methods in lignin chemistry. Berlin: Springer-Verlag; 1992. 578p.

Liu ZG, Han GH. Production of solid fuel biochar from waste biomass by low temperature pyrolysis. Fuel. 2015;158(15):159-65.

Luna JAN, Medrano JAS, Gonzalez JM. Short communication. Lumber yield and production time in sawmilling of pallets in Durango, Mexico. Forest Systems. 2013;22(3):573-7.

Mészáros E, Jakab E, Várhegyi G. TG/ MS, Py-GC/ MS and THM-GC/MS study of the composition and thermal behavior of extractive components of Robinia pseudoacacia. Journal of Analytical and Applied Pyrolysis. 2007;79(1):61-70.

Mitchell SJ. Wind as a natural disturbance agent in forests: a synthesis. Forestry. 2012;86(2):147-57.

Moore JR, Manley BR, Park D, Scarrott CJ. Quantification of wind damage to New Zealand's planted forests. Forestry. 2013;86(2):173-83.

Moreno AI, Font R. Pyrolysis of furniture wood waste: decomposition and gases evolved. Journal of Analytical and Applied Pyrolysis 2015;113(1):464-73.

Pereira BLC, Carneiro ACO, Carvalho AMML, Colodette JL, Oliveira AC, Fontes MPF. Influence of chemical composition of eucalyptus wood on gravimetric yield and charcoal properties. Bioresources. 2013;8(3):4574-92.

Pirralho M, Flores D, Sousa VB, QuilhóT, Knapic S, Pereira H. Evaluation on paper making potential of nine Eucalyptus species based on wood anatomical features. Industrial Crops and Products. 2014;54(2):327-34

Prasad L, Salvi BL, Kumar V. Thermal degradation and gasification characteristics of Tung Shells as an open top downdraft wood gasifier feedstock. Clean Technologies and Environmental Policy. 2015;17(6):1699-706.
Oliveira JB, Mendes MG, Gomes PA. Produção de carvão vegetal: aspectos técnicos. In: Fundação Centro Tecnológico de Minas Gerais. Produção e utilização de carvão vegetal. Belo Horizonte: 1982. p.62-73.

Severo ETD, Sansígolo CA, Calonego FW, Barreiros RM. Kraft Pulp from Juvenile and Mature Woods of Corymbia citriodora. Bioresources. 2013;8(2):1657-64.

Sjöströn E. Wood chemistry. Nova York: Academic Press; 1981.

Soares VS, Bianchi ML, Trugilho PF, Júnior Pereira A, Höfler J. Correlações entre as propriedades da madeira e do carvão vegetal de híbridos de eucalipto. Revista Árvore. 2014;38(4):543-9.

Sousa VB, Cardoso S, Pereira H. Ring width variation and heartwood development in Quercus faginea. Wood and Fiber Science. 2013;45(4):405-14.

Ramírez M, Rodríguez J, Peredo M, Valenzuela S, Mendonça R. Wood anatomy and biometric parameters variation of Eucalyptus globulus clones. Wood Science and Technology. 2009;43(1):131-41.

Rousset P, Figueiredo C, Souza M, Quirino W. Pressure effect on the quality of eucalyptus wood charcoal for the steel industry: a statistical analysis approach. Fuel Processing Technology. 2011;92(10):1890-7.

Varfolomeev MA, Grachev AN, Makarov AA, Zabelkin SA, Emel'yanenko VN, Musin TR, et al. Thermal analysis and calorimetric study of the combustion of hydrolytic wood lignin and products of its pyrolysis. Chemistry and Technology of Fuels and Oils. 2015;51(1):140-5.

Veenin T, Fujita M, Nobuchi T, Siripatanadilok S Radial variations of anatomical characteristics and specific gravity in Eucalyptus camaldulensis Clones. IAWA Journal. 2005;26(3):353-61.

Zanuncio AJV, Carvalho AG, Trugilho PF, Monteiro TC. Extractives and energetic properties of wood and charcoal. Revista Árvore. 2014;38(2):369-74. 